\title{
Managing Agent Service Quality Performance Framework on Strata Housing Scheme Management
}

\author{
Wan Zahari Wan Yusoff, Shamre Liew \\ Department of Real Estate Management \\ Faculty of Technology Management \& Business \\ University Tun Hussein Onn \\ Malaysia
}

\begin{abstract}
Issues pertaining to weaknesses of service delivery by Managing Agent (MA) in strata housing schemes gain a serious and continuous attention by many parties. In this context, the term Managing Agent refers to the Joint Management Body $(\mathrm{JMB})$ and Management Corporation (MC) that can be found in a stratified residential property. Among other issues that consistently being highlighted include several aspects such as maintenance, complaints on property damages, security and resident's welfares. Studies on Service Quality (SERVQUAL) had been conducted in most services industries including banking, retails, telecommunications, real estate agency, local authorities etc. Nevertheless, studies on service quality performance of strata housing schemes are still under-researched. Thus, this research seeks to study the Service Quality (SERVQUAL) performance delivered by Managing Agent in strata housing schemes. The main objective of the research study is to evaluate the resident's expectation and perception towards the service quality performance delivered by the managing agents. The second objective is to reveal the gap between the resident's expectation and perception towards the quality of service. This research study had selected 10 condominiums and apartments around Kuala Lumpur as its case study. As many as 30 questionnaire surveys were distributed to each of the selected condominium and apartment residents to reach a total of 300 respondents. It was recognized that there are five generic dimensions in the measurement of Service Quality (SERVQUAL) which are "Tangible", "Reliability", "Responsiveness", "Assurance" and "Empathy" and a total of 22 statements of expectation and 22 statements of perceptions were developed to measure the Managing Agents Service Quality on strata housing scheme management. In the research study, frequency Analysis was used to determine the mean score for each statement and subsequently identifying the Service Gap. The results show that the highest expectation of the residents is the "Assurance" dimension whereby the residents expect the employee of excellent Managing Agent have the knowledge to answer their inquiries. Meanwhile the highest perception is the "Empathy" dimension whereby the Managing Agent employees understand the resident's specific needs. The analysis also reveals that the largest Service Gap was found in "Assurance" dimension followed by "Reliability" and "Responsiveness" dimensions. In conclusion, the research study managed to evaluate the highest expectation and perception of the residents in the strata housing scheme and also identifying Service Gaps between the resident's expectation and perception towards service quality provided by the Managing Agent. The outcome has alerted the Managing Agents to take immediate corrective action to improve the quality of service to the residents in the strata housing schemes.
\end{abstract}

\section{Indexing terms/Keywords}

Service Quality (SERVQUAL), Strata Housing Scheme, Managing Agent, Expectation, Perception, Service Gap

Academic Discipline And Sub-Disciplines

Social Science; Economics; Real Estate Economics

\section{SUBJECT CLASSIFICATION}

Consumer Service, Service Quality, Housing Management

TYPE (METHOD/APPROACH)

Survey and Interview

\section{Council for Innovative Research}

Peer Review Research Publishing System

Journal of Social Science Research

\author{
Vol.3, No.3 \\ editor@cirworld.com \\ www.cirworld.com, member.cirworld.com
}




\section{INTRODUCTION}

The scarcity of land supply in Kuala Lumpur has resulted in the decline of landed residential property development in the center and surrounding area of the city. This drawback was significantly contributed by the dramatic increase in the number of population in the capital city of Malaysia. According to the Statistic Department, the number of population in Kuala Lumpur in year 2012 was recorded at 1.7 million. With a land area of 243 square kilometers, the development of landed residential property is no longer be seen as a practical approach to accommodate the increasing number of people living in the area. Property developers are now focusing on developing strata property schemes such as condominium and apartment that come with extra property features and slightly higher price to compensate the shortcomings of landed property. According to a report by the National Property Information Centre (NAPIC), up to the fourth quarter of year 2012 (Q4), there were about 2,530 number of strata residential properties such as condominium and apartment have been transacted in Kuala Lumpur and another 1,195 unit have been transacted in first quarter 2013.

Practically, developing more strata scheme means more numbers of managing agent are required to manage and upkeep the property. Hence, one of the most unavoidable issues pertaining to the development of high rise residential property would be the quality of services provided by the managing agents namely Joint Management Body (JMB) and Management Corporation (MC) to the residents in the strata housing scheme. In order to retain the current and prospect tenants of the property and to increase the long term investment value, property managers of strata housing schemes must ensure that the quality of services provided to the residents are adequately satisfactory and achieve the level of expectation among the residents. As such, Service Quality (SERVQUAL) is an instrument that can be used to measure the performance of service quality provided by a service provider to the customers. In this research study, SERVQUAL is applied to evaluate the performance of service quality delivered by the appointed managing agents in the 10 selected condominium and apartment in Kuala Lumpur vicinity.

\section{ISSUES}

A number of previous studies related to Service Quality and SERVQUAL in various sectors and service business operations namely financial services (Aymn, 2013), public services (Himurkhe, 2013), healthcare (Francescsa \& Harini, 2013), education (Anthony \& Shaheen, 2013), tourism and hospitality (Mushtaq, 2013) and transportation (Randheer, 2011) have been widely discovered. However, studies on service quality performance among managing agents in strata housing schemes are yet to be extensively carried out.

Management Agent namely Joint-Management Body (JMB) or Management Corporation (MC) is the appointed body that responsible to provide services to the residents residing in a strata housing scheme such as condominium and apartment. Typical services that can be found in a strata housing scheme are such as tenants book-keeping and account services, security system, repair and maintenance and basic facilities such as lifter, gymnasium, swimming pool and so forth. As tenants are obliged to pay rent every month, they expect to get quality services and quick response to any complaints should there be any incidents of breakdown with their properties from the appointed managing agent. A satisfactory service provided by the management to the residents of the housing scheme will ensure a longer tenancy dwelling in the housing scheme. A number of complaints were received from the residents in regards to the quality of services delivered by the managing agent who was appointed to manage the strata scheme. The current practice of property management in high-rise residential property in this country is focusing more on physical element and structures and is not really giving attention to other aspects such as being responsive to residents' complaints and keeping up a good relationship with the residents (Tiun Ling Ta, 2007). Furthermore according to Tiun (2007), most property managers whether they are registered or not will only take action if there were complaints from the resident. No initiative being taken to improve the quality of life of the residents what more to increase the value of the property under their management.

In the study conducted by Abdul Latif Azmi and Noraziah Azmin (2006) on problems faced by property management in managing high rise condominium in Malaysia found that the common complaints lodged by tenants is defects in their unit not attended within the time specified. The slow response by the management has resulted to other problems such as poor collection of maintenance fees from the residents as they did not satisfied with the maintenance work conducted by the property managers in their unit.

\section{OBJECTIVES}

The research study has 2 (TWO) main objectives:

i. To evaluate the residents' expectation and perception towards the Service Quality (SERVQUAL) performance delivered by the managing agents in the strata housing scheme in Kuala Lumpur

ii. To reveal the gap between the residents' expectation and perception on the Service Quality to be forwarded to the managing agency for improvement

\section{RELATED WORKS}

Service quality is associated with customer satisfaction towards the quality of goods or services provided by an organization or firm. This was supported by Parasuraman, Zeithaml and Berry (1995) who defined service quality as an extension of a service provided achieved or exceeded customer expectation. Bitner, Booms and Mohr (1994) defined service quality as 'the consumer's overall impression of the relative inferiority / superiority of the organisation and its services'. Other researchers namely Cronin and Taylor (1994), Taylor and Cronin (1994) view service quality as a form of attitude representing a long-run overall evaluation. In marketing, service quality means understanding the customers' needs and identifying ways to meet or exceed them. It is sometimes equated with customer satisfaction, or the degree to 
which customers' perceptions of the service meet or exceed their expectations of the service transaction (Randall and Senior, 1992).

Customer satisfaction reflects the performance of the organization whereby in Hoffman and Bateson (1997), service quality is an attitude formed by a long-term, overall evaluation of a performance. Thus, service quality can be described as the differences between customer expectation and perception of service. Therefore, it can be said that should the expectations are greater than performance, the perceived quality is less than satisfactory and thus leads to dissatisfaction by customer (Parasuraman et al., 1985). Further, according to Zeithaml and Bitner (1996), service quality is the delivery of excellent or superior service relative to customer or superior relative to customer expectations. Therefore, service quality can be simplified as an evaluation between customer expectation and perception. To further understand the core concept and principles of service quality, Parasuraman et al., (1985) have outlined three fundamental subjects with regards of service quality:
i. $\quad$ Service quality is more difficult for the customer to evaluate than goods quality
ii. Service quality perceptions result from a comparison of customer expectations with perceptions of actual service performance
iii. Quality evaluation is not made solely on the outcome of service but also involved evaluations of the process of service delivery

Table1 shows the Groonroos Dimension of Perceived Service Quality.

Table 1: Gronroos Dimension of Perceived Service Quality

\begin{tabular}{|c|c|}
\hline Dimension & Definition \\
\hline Professionalism and Skills & $\begin{array}{l}\text { Do the employees, physical resources and operational } \\
\text { systems of the organization have the knowledge and } \\
\text { skills to solve customer problems in a professional } \\
\text { way? }\end{array}$ \\
\hline Attitudes and Behaviors & $\begin{array}{l}\text { Do the service employees (contact person) show } \\
\text { concern for customers and interest in solving their } \\
\text { problems in a friendly and spontaneous way? }\end{array}$ \\
\hline Accessibility and Flexibility & $\begin{array}{l}\text { Is the service provider (e.g., its location, operating } \\
\text { hours, employees, operational systems) designed so } \\
\text { that customers can access the service easily and so } \\
\text { that the provider can adjust to the demands and } \\
\text { wishes of a customer in a flexible way? }\end{array}$ \\
\hline Reliability and Trustworthiness & $\begin{array}{l}\text { Do the customers know that they can rely on the } \\
\text { service provider, its employees and its systems to keep } \\
\text { promise and perform with the best interest of the } \\
\text { customer at heart? }\end{array}$ \\
\hline Recovery & $\begin{array}{l}\text { Do the customers realize that whatever something } \\
\text { goes wrong or something unpredictable happens, the } \\
\text { service provider will immediately take steps to keep the } \\
\text { customer in control and to find an acceptable new } \\
\text { solution? }\end{array}$ \\
\hline Reputation and Credibility & $\begin{array}{l}\text { Do the customers believe that the operations of the } \\
\text { service provider can be trusted and give adequate } \\
\text { value for the money and that it stands for good } \\
\text { performance and values which can be shared by } \\
\text { customers and the service provider? }\end{array}$ \\
\hline
\end{tabular}

\subsection{Methods of Measuring Service Quality}

The measurements of service quality have been developed since the last few decades. Kunst and Lemmink (1994) found that in many literatures reviewed, most of the service quality models work with expectations (Parasuraman, Zeithaml and Berry 1988, Buswell 1986, Liljander and Strandvik 1992, 1993).

According to Kunst and Lemmink (1994), customer compares his expectations towards a certain service with its perceived performance. The judgment of quality is built up on the basis of this theoretical construct. Better service quality evaluation develops when perceptions exceed or equal to expectations. Consequently, most approaches try to measure direct or indirect disconfirmation (Liljander and Strandvik 1993). Because there are different kinds of expectations such as idealism, predictive, minimal, product-type and brand-oriented of which different methods lead to different results. One model distinguishes customer-perceived service quality between 'technical quality' (what is delivered) and 'functional quality' (how it is delivered) (Gronroos, 1984). The first determinant concerns on the production of the core benefit of the service which relates to the traditional quality control in manufacturing, while the second determinant refers to the way the service is delivered and it involves the service-provider and the customers. This determinant is critical to perceptions of service quality.

4.2 SERVQUAL

Measuring customer's satisfaction is a subjective matter. Oliver (1981) defines satisfaction as a summary psychological state resulting when the emotion surrounding disconfirmed expectations is coupled with the consumer's prior feelings 
about the consumption experience. Since one's experience differs from another person, thus measuring satisfaction requires a substantial approach by researchers.

One alternative way of looking at customer's satisfaction is to measure customer expectations against customer perceptions in regards of the service delivery. This method is known as SERVQUAL. According to Parasuraman et al., (1988), SERVQUAL is a concise multiple item scale with good reliability and validity that retailers can use to better understand the service expectations and perceptions of consumers, and as a result improve service. It is the only method that suggests quantitative measurement of service quality that is simple to administer and is well accepted by many researchers and practitioners.

The difference between customer expectations and perceptions will result to a service gap. Thus, SERVQUAL can also be used as a tool to analyze the service quality gap between organizations. Basically, SERVQUAL is an empirically derived method used by organizations that provide services to improve the services in the interest of the customers.

Further according to Parasuraman et al., (1988), this instrument has been used by different industries as a tool to measure service quality since it is applicable across a wide spectrum of services. Thus, SERVQUAL is a powerful tool as it enables a researcher to break down services into five dimensions and subsequently to focus on improvement specifically at those stated dimensions. Table 2 shows the five (5) generic dimensions of service quality and explanation by Parasuraman et al $(1985,1988,1994)$.

Table 2: SERVQUAL Dimension and Definition

\begin{tabular}{|c|c|}
\hline Dimension & Definition \\
\hline Reliability & $\begin{array}{l}\text { Delivering the promises performance dependably and } \\
\text { accurately }\end{array}$ \\
\hline Tangibles & $\begin{array}{l}\text { Appearance of the organization's facilities, employees, } \\
\text { equipment and communication materials }\end{array}$ \\
\hline Responsiveness & $\begin{array}{l}\text { The willingness of the organization to provide prompt } \\
\text { service and help customers }\end{array}$ \\
\hline $\begin{array}{c}\text { Assurance (Combination of items designed originally } \\
\text { to assess Competence, Courtesy, Credibility and } \\
\text { Security }\end{array}$ & $\begin{array}{c}\text { The ability of the organization's employees to inspire } \\
\text { trust and confidence in the organization through their } \\
\text { knowledge and courtesy }\end{array}$ \\
\hline $\begin{array}{c}\text { Empathy (Combination of items designed originally to } \\
\text { assess Access, Communication and Understanding } \\
\text { the customer) }\end{array}$ & Personalized attention given to a customer \\
\hline
\end{tabular}

Source: Parasuraman et al., (1985, 1988, 1994)

The above dimensions were normally being taken by customers to make an evaluation on the service quality which was depending on what they expected and perceived on the services that they have experienced. The SERVQUAL instrument consists of two sections. The first section is the section which consists of 22 -items to record customer's expectations of excellent firm in the specific service industry while the second section which is also consists of 22 items used to measure customer's perceptions of a particular company in the service industry. Subsequently, the output from both sections is compared to produce the so-called 'gap scores' for each of the five dimensions. A wide gap would represent the poor service quality and shows that the service provider needs to improve on the service offered to its customers. In contrast, the smaller the gap, the higher the service quality is being evaluated.

\subsection{Service Quality Gaps Model}

According to Brown and Bond (1995), "the gap model is one of the best received and most heuristically valuable contributions to the services literature". The model identifies seven key discrepancies or gaps relating to managerial perceptions of service quality, and tasks associated with service delivery to customers. The first six gaps (Gap 1, Gap 2, Gap 3, Gap 4, Gap 6 and Gap 7) are identified as functions of the way in which service is delivered, whereas Gap 5 pertains to the customer and as such is considered to be the true measure of service quality. The Gap on which the SERVQUAL methodology has influence is Gap 5. 


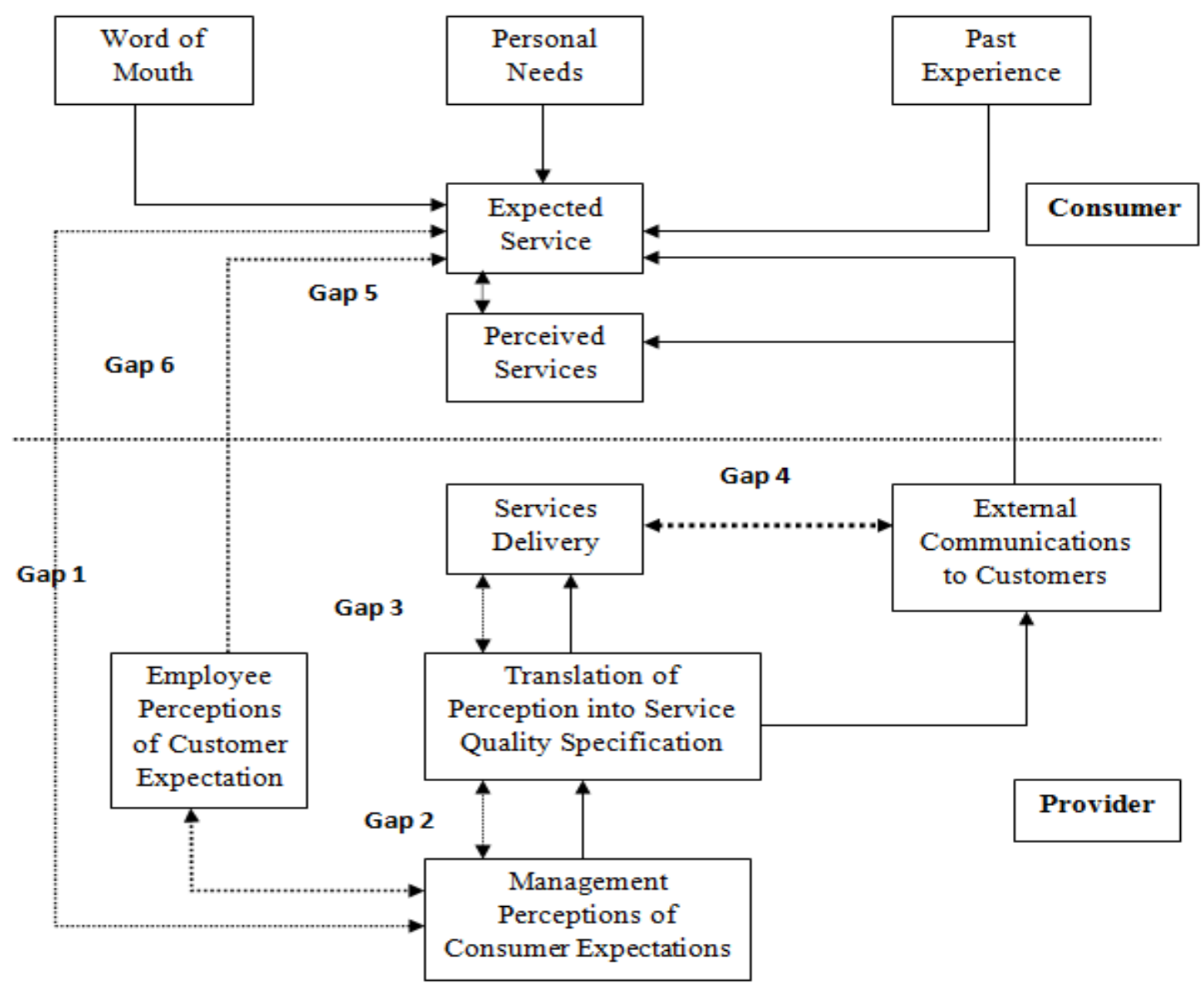

Figure 1: Service Quality Gap Model

This model stated that service quality is a cumulative measure of the overall quality performance of an organization and allowed for changes in customer's expectations and perceptions over time. Zeithaml, Parasuraman and Berry (1990) embarked upon a multiphase research study in 1983 which examined service quality. The data they collected helped them identify four internal gaps within service organizations that cause a discrepancy between what customers expect from a service and what they think they received. The researchers formalized these observations in a conceptual model (Zeithaml et al., 1990). Gap 1 is the difference between customers' expectations of the service and management's perception of customers' expectations. Customers form their expectations through word-of-mouth communications, personal needs, past experience, and communications from the service organization. Gap 2 is the difference between what managers perceive as customers' expectations and what they establish as service specifications. Gap 3 exists as the difference between service specifications and actual firm performance. This may be due to the inability or unwillingness of service employees to do what the firm has specified. Gap 4 is the discrepancy between what a firm promises about a service and what it actually delivers. These four internal gaps contribute to the most important gap of all, Gap 5, the difference between what a customer expects from a service and what he/she perceives the organization delivers. Gap6, the discrepancy between customer expectations and employees' perceptions: as a result of the differences in the understanding of customer expectations by front-line service providers. Gap7, the discrepancy between employee's perceptions and management perceptions: as a result of the differences in the understanding of customer expectations between managers and service providers.

\subsection{Customer Expectations, Perceptions and Satisfaction}

Armand (1992) explained that customers' expectations are sometimes difficult to identify. Customers are not always conscious of the prior expectations and when asked, they will often find it difficult completely accurately and articulate their expectations for a given service. A further difficulty is that their needs and wishes will change over time and from situation to situation. The old quality challenge of meeting or exceeding customer expectations now has a new emphasis on meeting or exceeding customers' expectations when those expectations are changing on virtually a daily basis.

In normal circumstance, customer perceptions appeared when he or she has experienced the product or service. Perceptions tend to be positive or negative depending on the customer's evaluation of the product or service. However, in the service industry customer normally perceives services in terms of quality of the service and to what extent they are satisfied with the overall experience of the service (Zeithaml et al., 2006). John and Fornell (1991) define customer satisfaction as cumulative impression of a firm's service performance. According to Boulding et al., (1993), customer satisfaction can be defined using the transaction-specific perspective or cumulative perspective. The transaction- specific 
perspective indicates that customer satisfaction is the evaluation based on the recent purchase experience. Nevertheless, customer satisfaction in services industry is always associated with the quality or service delivered by the company or organization.

\section{RESEARCH METHODOLOGY}

The SERVQUAL approach was intentionally developed by Parasuraman et al., in 1988 to measure the service quality provided in the service industry. In constructing the instrument of SERVQUAL, Parasuraman et al., (1988) used disconfirmation paradigm approach. In this approach, the experience of an individual was compared with his or her expectation of which it consists of five service quality dimensions which are tangibles, reliability, responsiveness, assurance and empathy. For the purpose of future research, the author permitted other researchers to apply the dimension and recommend alteration or amendment to reflect the evaluation of the service. Originally, the SERVQUAL instruments consist of two segments of which the first segment encompasses of 22 items that records customer expectation of excellent firms in the specific service industry. Whilst, 22 items were set in the second segment which measures customer's perceptions of a related company in that particular service industry. Subsequently, the results from both segments are compared to attain the gap score for each of the five dimensions of service quality. The wider the score of the gap, the farther the customer perception is from the expectation and the lower the service quality being assessed. Hence, SERVQUAL in overall comprises of a 44 item scale that were used to measure customer's expectation and perception toward the five main service quality dimensions. In measuring the service quality dimension, a seven point scale with anchor labels of "Not Essential" and "Absolutely Essential" were used in the first segment to measure customer's expectations and correspondingly in segment two where another seven point of scale with anchor labels of "Strongly Agree" and "Strongly Disagree" were applied to measure customer's perceptions. For the purpose of this research, some adjustment of the original SERVQUAL instrument was made to suit the scenario of the research. The Author has divided the questionnaire into three segments of which the first segment covers the demographic information of the respondent of the 10 selected strata housing scheme. Second segment consists of the expectation statements from the respondents and the last segment consists of a statement that measures the perceptions of respondents.

\subsection{Resident's Expectations on Service Quality Framework}

i. Tangible Dimension

In this dimension, residents would observe physical products namely the tangible facilities provided by the management agency of the strata housing scheme. There are four expectation questions that were applied to excellent strata housing scheme management in order to obtain the SERVQUAL tangible component. They are:

E1 Excellent strata housing scheme management should have modern looking facilities.

E2 The physical facilities at excellent strata housing scheme management should be visually appealing

E3 Employee of excellent strata housing scheme management should be visually neat in appearance.

E4 Materials associated with the service such as pamphlets and notices should be visually appealing in an excellent strata housing scheme management.

\section{ii. Reliability Dimension}

Basically, reliability reflects the consistency and dependability of an organization's performance. This dimension observes on the level of service provided to the customer as to whether the service is delivered at the same level time after time or does the quality vary with each encounter. This dimension is also looking at the ability of the service provider to perform the promised service dependably and accurately. Other aspects are observed such as whether the organization keeps its promises, bills its customer accurately, keep accurate records and perform the service correctly the first time. Reliability dimension is perceived by the customer as the most critical part as failure in providing reliable services will translate into ineffective organization. Expectation statements concerning the reliability dimension are stated as follows:

E5 When excellent strata housing scheme management promise to do something by a certain time, they will do so.

E6 When the residents have a problem, excellent strata housing scheme management will show sincere interest in solving it.

E7 Excellent strata housing scheme management will perform service right the first time.

E8 Excellent strata housing scheme management provided their services at the time they promise to do.

E9 Excellent strata housing scheme management will insist on error free records.

\section{iii. Responsiveness Dimension}

Responsiveness concern on the willingness or readiness of employees to provide service. Simply, it reflects to the reaction of an organization to provide service in a timely manner. Occasionally, customers may come across with a situation in which employees of the organization engage with their own business and ignoring the needs of the customer. Following are the expectation statements concerning the responsiveness dimension.

E10 Employee of excellent strata housing scheme management will inform the residents exactly when services will be performed.

E11 Employees of excellent strata housing scheme management will give prompt service to residents. 
E12 Employee of excellent strata housing scheme management will always be willing to help.

E13 Employee of excellent strata housing scheme management will busy to respond to residents' requests.

\section{Assurance Dimension}

The assurance dimension relates to the knowledge and courtesy of employees and their ability to convey trust and confidence to the customer. Totally there are four aspects lying under the assurance dimensions which are Competence, courtesy, credibility and security of the service. Competence means possession of the required skills and knowledge to perform the service which involves knowledge and skills of the contact and operational support personnel. Access involves approachability and ease of contact in which service is easily accessible by telephone (the lines are not busy and employee does not put the customer on hold), waiting time to receive service is not extensive, convenient hours of operation and convenient location of service facility. Courtesy aspect involves politeness, respect, consideration and friendliness of contact personnel (including receptionist, telephone operator etc.) which includes the consideration for the customer's property as well as clean and neat appearance of public contact personnel. Credibility involves the elements of trustworthiness, believability and honesty of having customer's best interest at heart. Factors that contribute to credibility are such as the establishment of the company's name, company's reputation, personal characteristics of the contact personnel and the degree of hard sell involves interactions with customers. Last but not least is the security which involves the feeling of freedom from danger, risk or doubt. Examples are such as the property's security and financial security.

E14 The behavior of employee of excellent strata housing scheme management will instill confidence in residents.

E15 Residents of excellent strata housing scheme management will feel safe in their transactions.

E16 Employee of excellent strata housing scheme management will be consistently courteous to residents.

E17 Employee of excellent strata housing scheme management will have the knowledge to answer residents' questions.

v. Empathy Dimension

Empathy dimension portrays an attitude such as caring and giving individualized attention that the organization provides to its customers. It is the ability to experience another's feelings as one's own. Empathic organizations have not lost touch of what it is like to be a customer of their own organization. Following are the expectation statements that pertain to assurance dimension:

E18 Excellent strata housing scheme management will give residents individual attention.

E19 Excellent strata housing scheme management will have operating hours convenient to all residents.

E20 Excellent strata housing scheme management will have an employee who gives residents personal attention.

E21 Excellent strata housing scheme management will have the residents' best interest at heart

E22 The employee of excellent strata housing scheme management will understand the specific needs of the residents.

5.2

Resident's Perception on Service Quality Framework

A total of 22 statements that concern to the perceptions of the respondents with respect to the service quality delivered by the managing agents (MA). These statements were divided into five service quality dimensions which are tangible, reliability, responsiveness, assurance and empathy.

i)

Tangible Dimension

P1 Managing Agency has modern looking equipment.

P2 Managing Agency has physical facilities that are visually appealing.

P3 Employees of the Managing Agency are neat in appearance.

P4 Materials associated with the services (such as pamphlets or notices) are visually appealing at the strata housing scheme.

\section{ii) Reliability Dimension}

P5 When a Managing Agent promises to take action by a certain time, it does so.

P6 When having a problem, Managing Agent shows sincere interest to solve it.

P7 Managing Agent performs service right the first time.

P8 Managing Agent provided its service at the time it promises to do so.

P9 Managing Agent insists on error-free records.

iii) Responsiveness Dimension

P10 Employees of the Managing Agency inform the residents when the service will be performed.

P11 Employees of Managing Agency give the residents a prompt service.

P12 Employees of Managing Agency are always willing to help the residents.

P13 Employees of Managing Agency never too busy to respond to the residents' requests.

iv) Assurance Dimension 
P14 The behavior of Managing Agency employees instill confidence in residents.

P15 The residents feel safe in the transactions made by the Managing Agent.

P16 Employees of Managing Agency are consistently courteous to the residents.

P17 Employees of the Managing Agency have the knowledge to answer the residents' questions.

\section{v) Empathy Dimension}
P18 Managing Agency gives the residents individual attention.
P19 Managing Agency operating hours are convenient to the residents.
P20 Managing Agency has employees that give the residents personal attention.
P21 Managing Agent has the residents' best interests at heart.
P22 Employees of Managing Agency understand the residents' specific needs.

According to Losardo and Rossi, (1993) there are several points that a researcher should bear in mind when developing and applying the SERVQUAL instrument which can be observed as follows:

a) Expectation should be generic for the service. It means that all the expectation statements in the first segment of the questionnaire surveys should be dealing with the service in general, not the service offered by a particular provider.

b) Perceptions should be specific to the service provider. It means that the name of the service organization should appear in the process of assessing the perception statements from the respondents.

c) Only one service aspect should be covered by a statement. This is to avoid confusion among the respondents should more than one aspect is covered.

d) Expectation and perception statement should have parallel wording. This is to assist the respondent to make a clear cut comparison between both statements.

e) Statements should describe unambiguous behaviors. This is to ensure that the statements are precisely delivered to the respondents and trying to not include vague terms.

f) Statement should focus on the positive aspect of the service of which it means that the statements pairs should emphasize the desired service in positive terms. This is to make sure that the computation of gap scores becomes easier.

\subsection{Survey and Analysis}

The questionnaire was divided into three segments. The first segment was a close ended question constructed to gather background information of the respondents. Meanwhile, the second segment was intending to measure the residents' expectation by using a seven point scale with anchor labels of 'not at all essential' and 'absolutely essential' and the third segment measured the residents' perception on a seven point scale with the anchor labels of 'strongly disagree' and 'strongly agree'. The questionnaire survey was distributed to the respondents by way of face to face approach. In this approach, the author went to the strata housing scheme to personally meet up with the residents and distribute the questionnaires to the residents and getting back the response directly from the respondents.

After all data and information have been gathered back from the surveys, subsequently the data will be transferred to statistical analysis software called SPSS version 16.0 to get the results. Analysis by SPSS version 16.0 would achieve the first objective of the research. Then, the output from SPSS analysis was transferred to Microsoft Excel to accomplish the second objective. Once the data collection process is completed, the analyst begins to explore the data, by measuring the central tendency of the data, and more importantly, the dispersion of the data around this central tendency. Frequency analysis is particularly useful for describing discrete categories of data having multiple choice or yes-no response formats. This analysis involves constructing a frequency distribution. The frequency distribution is a record of the number of scores that fall within each response category. The frequency distribution, then, has two elements: (1) the categories of response, and (2) the frequency with which respondents are identified with each category.

\subsection{Gap Analysis}

The gap analysis model was used to find the differences between customer's expectation and perception towards service quality provided by a service organization. The gap between customer's expectation and perception can be taken as a measure to improve the current service quality of the organization. According to Zeithaml et al. (1991), the difference between desired expectation level and the perceived delivery is the perceived service superiority, while the difference between adequate expectations and perceived delivery is the perceived service adequacy. The discrepancy between predicted offering and perceived delivery is supposed to determine the satisfaction of the product. Gap analysis was used to measure how wide the gap between customer's expectation and perception is. Simply, it can be written as the following equation:

\section{Gap Analysis = Perception's Score - Expectation's Score}

According to Dean (1999), the usefulness of the SERVQUAL gap score as compared to performance only scores (Cronin and Taylor, 1992; Parasuraman et al., 1994) and concluded that performance only measures can be used to assess quality, but the study supports the use of gap scores because of their diagnostic value. The study was in line with Parasuraman et al., who maintain that whilst performance only measures of quality may be reliable predictors of overall quality, SERVQUAL scores could be superior in terms of pinpointing areas of deficiency within an organization.

\section{RESULTS AND DISCUSSIONS}


The first analysis is to show the profile of respondents involved in the research by using the Frequency Analysis. Subsequently, the analysis of Mean was applied to rank the expectation and perception statements of the respondents towards the service quality provided by the managing agent according to the service quality dimension. Resultants from the mean gap analysis were subsequently used to determine the gap between the respondent's expectation and perception towards the service quality. Table 3 shows the number of questionnaires distributed to the managing agents according to type of condominiums/ apartments. A total number of 300 set of questionnaire survey forms were distributed to the residents of 10 condominiums and apartments (A-J) in Kuala Lumpur . 30 survey forms were distributed to each strata scheme. This survey was carried out on a face-to-face approach where the researcher has visited the site to meet the respondents to get feedback from the residents regarding their expectation and perception towards the service quality delivered and provided by the appointed managing agents in the strata housing scheme.

Table 3: Number of Questionnaire Surveys To Respondents

\begin{tabular}{|c|l|c|}
\hline Condominium / Apartment & \multicolumn{1}{|c|}{ Managing Agents } & Survey Distribution \\
\hline A & Rahim \& Co & 30 \\
\hline B & Raine \& Horne & 30 \\
\hline C & DTZ Nawawi Tie \& Leung & 30 \\
\hline D & Azmi \& Co & 30 \\
\hline E & Knight Frank & 30 \\
\hline F & CH William & 30 \\
\hline G & Malik \& Kamaruzaman & 30 \\
\hline H & TD Aziz & 30 \\
\hline I & KJ Properties & 30 \\
\hline J & YY Property Solution & 30 \\
\hline & Total & $\mathbf{3 0 0}$ \\
\hline
\end{tabular}

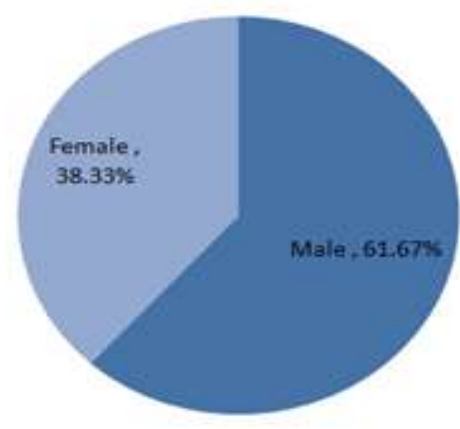

Figure 1: Respondent's Gender

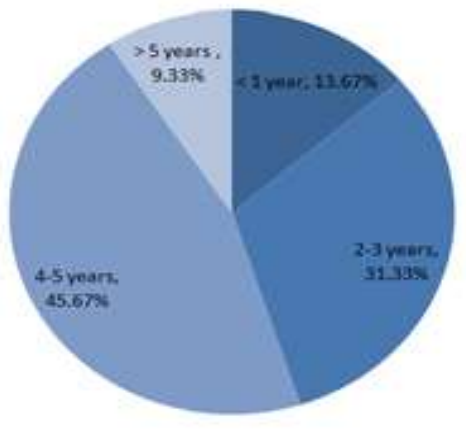

Figure 2: Length of Occupancyl

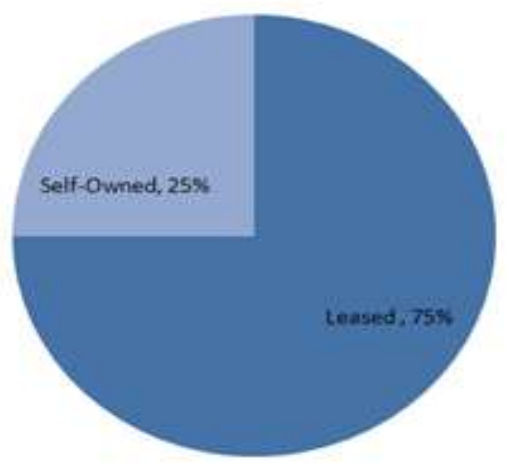

Figure 3: Type of Ownership

Figure 1 depicts that $61.67 \%$ or 185 respondents involved in the survey were male residents while $38.33 \%$ or 115 respondents were female. Figure 2 shows the length of occupancy period of the residents involved in the survey. Residents with a lengthy occupancy period are assumed to have more experience with the services delivered by the managing agent. It can be seen that 137 of the respondents or $45.67 \%$ of them had occupied the strata housing scheme for the around 4 to 5 years. This is followed by 94 or $31.33 \%$ of the residents have been living there between 2 to 3 years. Residents with less than 1 year occupancy period was recorded at $13.67 \%$ and residents who have resided at the strata 
housing scheme for more than 5 years were as many as 28 persons or $9.33 \%$. Figure 3 shows that the majority of the respondents involved in the survey leased the property with 225 respondents or $75 \%$ while 75 of the respondents or $25 \%$ owned or purchased the condominium or apartment unit. Type of ownership is one of the important details required to represent the resident's commitment towards the strata property.

\subsection{Residents' Expectation and Perception Towards Service Quality}

The results of expectation and perception of the residents towards the service quality provided by the managing agents were presented by using frequency analysis and compare mean approach to determine the highest and lowest score for both expectation and perception statements. The highest mean score reflected the most important statement selected by the respondents while the lowest mean score represented the least important statement observed by the respondents.

\subsubsection{Five Highest Expectations \& Perceptions}

Table 4 shows the five highest statements that the residents had expected and perceived from the managing agents. It can be seen that the "Assurance" dimension recorded the highest expectation mean score of 6.67 with the statement of "Employee of excellent strata housing scheme management will have the knowledge to answer residents' questions". This statement shows that the residents have high expectation to the management in terms of having the credibility to answer any question or problem pertained to their property interest. This is a very crucial element to retain the resident's loyalty and occupancy length in the strata housing scheme. This included several aspects such as maintenance, security or any issues that related to their interests as residents in the strata housing scheme.

Table 4: Resident's Highest Expectation \& Perception

\begin{tabular}{|c|c|c|c|c|c|c|}
\hline & Dimension & Statements & $\begin{array}{l}\text { Mean } \\
\text { Score }\end{array}$ & Dimension & Statements & $\begin{array}{l}\text { Mean } \\
\text { Score }\end{array}$ \\
\hline 1 & Assurance & $\begin{array}{l}\text { Employee of } \\
\text { excellent strata } \\
\text { housing scheme } \\
\text { management will } \\
\text { have the knowledge } \\
\text { to answer residents' } \\
\text { questions }\end{array}$ & 6.67 & Empathy & $\begin{array}{l}\text { Employees of the } \\
\text { MA understand the } \\
\text { residents' specific } \\
\text { needs }\end{array}$ & 6.77 \\
\hline 2 & Responsiveness & $\begin{array}{l}\text { Employee of } \\
\text { excellent strata } \\
\text { housing scheme } \\
\text { management will } \\
\text { always be willing to } \\
\text { help }\end{array}$ & 6.57 & Responsiveness & $\begin{array}{l}\text { Employees of the } \\
\text { MA never too busy } \\
\text { to respond to the } \\
\text { residents' requests }\end{array}$ & 6.68 \\
\hline 3 & Assurance & $\begin{array}{l}\text { Employee of } \\
\text { excellent strata } \\
\text { housing scheme } \\
\text { management will be } \\
\text { consistently } \\
\text { courteous to } \\
\text { residents }\end{array}$ & 6.52 & Reliability & $\begin{array}{l}\text { The MA provides } \\
\text { its service at the } \\
\text { time it promises to } \\
\text { do so }\end{array}$ & 6.00 \\
\hline 4 & Reliability & $\begin{array}{l}\text { When the residents } \\
\text { have a problem, } \\
\text { excellent strata } \\
\text { housing scheme } \\
\text { management will } \\
\text { show its concern in } \\
\text { solving it }\end{array}$ & 6.48 & Assurance & $\begin{array}{lr}\text { Employees of } & \text { MA } \\
\text { have } & \text { the } \\
\text { knowledge } & \text { to } \\
\text { answer } & \text { the } \\
\text { residents' } & \\
\text { questions } & \end{array}$ & 6.00 \\
\hline 5 & Assurance & $\begin{array}{l}\text { The employee of } \\
\text { excellent strata } \\
\text { housing scheme } \\
\text { management will } \\
\text { instill confidence in } \\
\text { residents }\end{array}$ & 6.37 & Reliability & $\begin{array}{l}\text { When the MA } \\
\text { promises to take } \\
\text { action by a certain } \\
\text { time, it does so }\end{array}$ & 5.95 \\
\hline
\end{tabular}

The second highest statement comes from the "Responsiveness" dimension in which the residents expected an excellent strata housing scheme managing agent should always be willing to help the residents on any matters in regards of their property. Apart from that, the residents also have high expectation of the management to be consistently courteous with the residents' needs, showing its concerns to solving the problems facing the residents and instill confidence in them through employees' behavior.

For perception dimension, the majority of the residents involved in the survey agreed that the managing agents understood the residents' specific needs with 6.77 of mean scores recorded from the "Empathy" dimension. Specific needs included the aspect of basic facilities that should be available in a strata housing scheme. Employees of the appointed managing agents never too busy to respond to the residents' requests from the "Responsiveness" dimension was in second place with 6.68 mean scores. This shows that the employees of the appointed managing agents always 
have ample time to entertain the residents' requests. Next, the residents of the selected condominium and apartment also perceived the managing agents managed to provide their services at the time it promised to do so. The appointed managing agents also observed as having the knowledge to answer the residents' questions especially in regards to their needs. Lastly, the residents perceived that the managing agents took actions by a certain time as they promised.

\subsubsection{Five Lowest Expectations \& Perceptions}

Table 5 represents the resident's five lowest expectations and perceptions of service quality performance on managing agents in the selected strata housing scheme in Kuala Lumpur. From the table, it clearly shows that the majority of the residents expected least on the "Tangible" dimensions. The lowest statement expected from the residents was "Employee of excellent strata housing scheme management should be neat in appearance" with 4.65 of mean scores.

Table 5: Resident's Lowest Expectation \& Perception

\begin{tabular}{|c|c|c|c|c|c|c|}
\hline & Dimension & Statements & Mean Score & Dimension & Statements & Mean Score \\
\hline 1 & Tangible & $\begin{array}{l}\text { Employee of } \\
\text { excellent strata } \\
\text { housing scheme } \\
\text { management } \\
\text { should be neat in } \\
\text { appearance }\end{array}$ & 4.65 & Responsiveness & $\begin{array}{l}\text { Employees of } \\
\text { MA inform the } \\
\text { residents when } \\
\text { the service will } \\
\text { be performed }\end{array}$ & 4.92 \\
\hline 2 & Tangible & $\begin{array}{l}\text { Materials } \\
\text { associated with } \\
\text { the service such } \\
\text { as pamphlets and } \\
\text { notices should be } \\
\text { visually appealing } \\
\text { in an excellent } \\
\text { strata housing } \\
\text { scheme } \\
\text { management }\end{array}$ & 5.08 & Reliability & $\begin{array}{l}\text { MA insists on } \\
\text { error-free } \\
\text { records }\end{array}$ & 4.96 \\
\hline 3 & Tangible & $\begin{array}{l}\text { The physical } \\
\text { facilities at } \\
\text { excellent strata } \\
\text { housing scheme } \\
\text { management } \\
\text { should be visually } \\
\text { appealing }\end{array}$ & 5.11 & Tangible & $\begin{array}{l}\text { Employees of } \\
\text { the MA are neat } \\
\text { in appearance }\end{array}$ & 5.04 \\
\hline 4 & $\begin{array}{l}\text { Responsivene } \\
\text { ss }\end{array}$ & $\begin{array}{l}\text { Employee of } \\
\text { excellent strata } \\
\text { housing scheme } \\
\text { management will } \\
\text { busy to respond to } \\
\text { residents' } \\
\text { requests }\end{array}$ & 5.40 & Reliability & $\begin{array}{l}\text { MA performs } \\
\text { service right the } \\
\text { first time }\end{array}$ & 5.45 \\
\hline 5 & Tangible & $\begin{array}{lr}\text { Excellent } & \text { strata } \\
\text { housing scheme } \\
\text { management } \\
\text { should have } \\
\text { modern looking } \\
\text { facilities }\end{array}$ & 5.41 & ible & $\begin{array}{l}\text { MA has modern } \\
\text { looking facilities }\end{array}$ & 5.52 \\
\hline
\end{tabular}

This shows that the residents are not taking the aspect of appearance among management's employees as an essential aspect in providing them with a quality service as most of the service works involved aspects such as maintenance, safeguarding, physical and technical works that did not require the employee to be neat in appearance. It also showed that appearance did not have a major impact on service quality performance Other least expected statements were such as materials used in the strata scheme to provide information, physical facilities should be visually appealing, availability of time to respond the residents' requests and modern looking of facilities at the strata housing scheme.

Meanwhile, "Responsiveness" dimension with a statement of "Employees of the appointed managing agents inform the residents when the service will be performed" was perceived as the lowest statement with 4.92 mean scores. That is due to the reason that the closing time between the management office and the residents where most of the residents were working during the day and some maintenance and repairing works were accomplished without the presence of the residents and thus causing residents not being informed about the maintenance work.

The second lowest perception was that the appointed managing agents insisted on error-free records with a mean score of 4.96. Apart from that, the residents of the selected strata scheme think that the employees of the managing agents are not neat in appearance. The reason could be due to the nature of work that the employees of the managing agents that did not require them to be neat in appearance. Other lowest statements perceived by the residents are concerned about the first time service performed by the managing agents with 5.45 mean scores and that the facilities available in the strata 
scheme were not modern-looking according to the residents. The low-perceived statements should be carefully looked by the management and rectifies the issues in order to improve the residents' perceptions towards the service quality provided by the managing agents.

\subsection{Service Gap Analysis on Resident's Expectation and Perception}

The differences between the resident's expectation and perception towards the service quality provided by the managing agent of the strata housing scheme are shown by using Gap Analysis. The following table shows the results of the gap analysis.

\subsubsection{Highest \& Lowest Service Gap}

The Table 6 shows some of the highest service gaps resulted from the expectation and perception statements. It can be seen that the highest service gap was the "Responsiveness" dimension with a statement of "Employees of the managing agents inform the residents when the service will be performed". The second highest service gap was from the "Assurance" dimension with a statement of "Employees of the managing agents are consistently courteous to the residents" followed by the "Reliability" and "Responsiveness" dimensions and lastly was another "Assurance" dimension with the statement of "The behavior of the managing agents employees instill confidence in residents".

Table 6: Highest and Lowest Service Gap

\begin{tabular}{|c|c|c|c|c|c|c|}
\hline & Dimension & Statements & Service Gap & Dimension & Statements & $\begin{array}{c}\text { Service } \\
\text { Gap }\end{array}$ \\
\hline 1 & $\begin{array}{l}\text { Responsivenes } \\
\text { s }\end{array}$ & $\begin{array}{l}\text { Employees of } \\
\text { the MA inform } \\
\text { the residents } \\
\text { when the } \\
\text { service will be } \\
\text { performed }\end{array}$ & -1.35 & Reliability & $\begin{array}{l}\text { When MA } \\
\text { promises to take } \\
\text { action by a } \\
\text { certain time, it } \\
\text { does so }\end{array}$ & -0.14 \\
\hline 2 & Assurance & $\begin{array}{l}\text { Employees of } \\
\text { the MA are } \\
\text { consistently } \\
\text { courteous to the } \\
\text { residents }\end{array}$ & -0.89 & Reliability & $\begin{array}{l}\text { MA provides its } \\
\text { service at the } \\
\text { time it promises } \\
\text { to do so }\end{array}$ & -0.21 \\
\hline 3 & Reliability & $\begin{array}{l}\text { MA performs } \\
\text { service right the } \\
\text { first time }\end{array}$ & -0.88 & Emp & $\begin{array}{l}\text { MA gives the } \\
\text { residents } \\
\text { individual } \\
\text { attention }\end{array}$ & -0.27 \\
\hline 4 & $\begin{array}{l}\text { Responsivenes } \\
\text { s }\end{array}$ & $\begin{array}{l}\text { Employees of } \\
\text { the MA always } \\
\text { willing to help } \\
\text { the residents }\end{array}$ & -0.88 & $\begin{array}{l}\text { Responsivene } \\
\text { ss }\end{array}$ & $\begin{array}{l}\text { Employees of } \\
\text { MA give the } \\
\text { residents } \\
\text { prompt service }\end{array}$ & -0.29 \\
\hline 5 & Assurance & $\begin{array}{l}\text { The } \\
311 \text { nstill311 of } \\
\text { the MA } \\
\text { employees } \\
\begin{array}{l}\text { 311nstill } \\
\text { confidence in } \\
\text { residents }\end{array} \\
\end{array}$ & -0.72 & Reliability & $\begin{array}{l}\text { MA insists on } \\
\text { error-free } \\
\text { records }\end{array}$ & -0.57 \\
\hline
\end{tabular}

Meanwhile, the lowest service gap is "Reliability" dimension with the statements such as "When managing agents promise to take action by a certain time, it does so", "Managing agent provided its service at the time it promises to do so" and "managing agent insists on error-free records". Other lowest service gaps are the "Empathy" and "Responsiveness" dimensions with the statements of "Managing agent gives the residents individual attention" and "Managing agent employees give the residents prompt service". The above lowest service gap statements indicate the statements that the residents are not really concern of. However, the management should not be ignoring of those aspects and should continue to maintain or improve the current service delivery to ensure long term satisfaction target can be achieved.

\subsection{Mean Expectation and Mean Perception by Dimension}

In Table 7 , the mean for expectation and perception according to its dimension is presented. Based on the table, it can be seen that the obvious gaps between the expectation and perception were from the "Assurance" dimension followed by "Reliability" and "Responsiveness" dimensions. Assurance dimension in this context relates to the knowledge and courtesy of employees and their ability to convey trust and confidence to the residents. Reliability dimension reflects the consistency and dependability of an organization's performance. Residents need a reliable managing agent in addressing all problems related to their unit of property so that sense of reliability and dependability can be developed in that regards. Meanwhile, Responsiveness dimension concerns on the willingness or readiness of employees to deliver services. In other words, it reflects to the reaction of an organization to provide a service in a timely manner.

However, the service gaps for "Tangible" and "Empathy" dimension were found to be in a positive position which means that the service quality performance perceived by the residents in those dimensions are exceeding their expectations.

\section{Table 7: Service Gaps Score}

\begin{tabular}{|l|l|l|l|l|}
\hline No & Dimension & Mean & Mean & Service \\
\hline
\end{tabular}




\begin{tabular}{|l|l|c|c|c|}
\hline & & Expectation & Perception & Gaps \\
\hline 1 & Tangible & 5.06 & 5.47 & 0.41 \\
\hline 2 & Reliability & 6.07 & 5.65 & -0.42 \\
\hline 3 & Responsiveness & 6.08 & 5.77 & -0.31 \\
\hline 4 & Assurance & 6.35 & 5.79 & -0.56 \\
\hline 5 & Empathy & 5.75 & 6.04 & 0.29 \\
\hline
\end{tabular}

\section{CONCLUSION}

Service quality is an important facet in the challenging business environment nowadays. To keep customer loyalty on a certain product or services may require a massive marketing strategy and efforts from the service provider. Excellent services can be well accepted when the service being delivered could meet or exceed the customer's expectation. However, satisfaction is not easy to measure and identify as it may vary from an individual to another individual. But the principle of service quality delivery remains the same of which customer would acknowledge if such service is delivered by quality.

SERVQUAL is a well-recognized instrument that was used to measure the level of service quality by counting of the customer's expectation and perception. The instrument was utilized by providing a set of questionnaire survey which comprised of 5 dimensions namely Tangible, Reliability, Responsiveness, Assurance and Empathy with 22 statements of customer's expectation and 22 statements of perception and subsequently the customer's feedback was obtained and generated from the questionnaire. The mean score for each statement was obtained and ranked accordingly to coordinate the customer's expectation adjacent to what the customer had perceived on the service delivery.

This research was carried out with the objectives to evaluate the expectation and perception of residents in the 10 selected strata housing scheme in Kuala Lumpur towards the service quality provided by the appointed managing agents. Apart from that, the study also brings forward the research findings to the management to take the necessary corrective action. In general, the objectives of this research were achieved as it had revealed the resident's level of expectation and perception towards the service quality performance of the selected managing agents. This research study found that the largest service gap was in the "Assurance" dimension followed by "Reliability" and "Responsiveness" dimensions. As such, the appointed managing agents should look carefully into the matter and rectify all complaints and issues pertaining to service quality in order to improve the level of satisfaction among the residents. Nevertheless, this research also had disclosed that the residents of the 10 selected condominium and apartment in Kuala Lumpur were satisfied with the "Tangible" and "Empathy" dimensions whereby the services delivered by the managing agent have exceeded the resident's expectation.

\section{REFERENCES}

[1] Abd Latif Azmi and Noraziah Azmin. 2007. The study of problems faced by property management in managing the high rise residential property in Malaysia. Universiti Teknologi Malaysia, Skudai Johor Malaysia.

[2] Anthony, V., and Shaheen, M. 2013. Malaysian Private Education Quality: Application of SERVQUAL Model. International Education Studies; Vol. 6, No. 4; 2013. Canadian Center of Science and Education.

[3] Armand, V.F. 1992. Quality is in its essence a way of managing the organisation, TQM Practitioners Series, Stanley Thornes, United Kingdom.

[4] Aymn., S. 2013. Basic Dimensions of the SERVQUAL Model and its impact on the level of customer satisfaction: An Empirical Study of the Housing Bank in Karak, Jordan. European Scientific Journal January 2013 edition vol.9.

[5] Boulding, W., Kalra, A., Staeling, R., and Zeithaml, V. A. 1993. A Dynamic Process Model of Service Quality: From Expectation to Behavioral Intentions. Journal of Marketing Research, 30(1), 7-27.

[6] Buswell, D.1986. The Development of a Quality Measurement System for a UK Bank, in: B. Moores (ed.), Are They Being Served?, Oxford, 1986 pg 141-155.

[7] Cooper, H.1998. Synthesizing Research: A Guidelines for Literature Review.

[8] Cronin, J. J., and Taylor, S.A. 1994. SERVPERF versus SERVQUAL: reconciling performance-based and perceptions minus expectation measurement of service quality. Journal of Marketing 58(1), 125-131.

[9] Fornell 1991. A Framework for Comparing Customer Satisfaction Across Individuals and Product Categories, Journal of Economic Psychology 12(2) (Fall), 267-286.

[10] Francesca, G., and Harini, N. 2013. Assessing obstetric patient experience: a SERVQUAL questionnaire, International Journal of Health Care Quality Assurance, Vol. 26 Iss: 7, pp.582 - 592.

[11] Gronroos, C. 1984, 1990. Service Management and Marketing: Managing the moments of truth in service competition, Lexington, MA: Lexington Books. 
[12] Hirmukhe and Jyotsna 2013. Measuring the customer's perception of service quality using SERVQUAL in public services. International Journal of Services Technology and Management, Volume 19, Numbers 4-6, pp. 267-277(11). Inderscience Publishers.

[13] Hoffman, K.D., and Bateson, J.E.G. 1997. Essentials of services marketing. Fort Worth: Dryden Press. Implications for Future Research," Journal of Marketing, pp. 41-50.

[14] Kunst, P.,and Lemmink, J. 1994. Managing Service Quality, Paul Chapman Publishing Ltd, United Kingdom. Liljander, V. and T. Strandvik (1992, 1993). Estimating Zones of Tolerance in Perceived Service Quality and Perceived Value, Working Paper 247, Swedish School of Economics and Business Administration, 1992.

[15] Losardo, M.M., and Rossi, N.M.1993. At the service quality frontier - A Handbook for managers, consultants and other pioneers. Wisconsin: ASQC Quality Press.

[16] Mushtaq., A.B. 2013. Tourism Service Quality: A Dimension-specific Assessment of SERVQUAL. Global Business Review June 2012vol. 13 no. 2 327-337

[17] National Property Information Centre Malaysia 2013.

[18] Nunnally, J. C. 1978. Psychometric theory (2 ${ }^{\text {nd }}$ ed.). New York: McGraw-Hill.

[19] Oliver, R. L. 1981. Measurement and Evaluation of Satisfaction Processes in Retail Settings. Journal of Retailing, 57(3), 25-48.

[20] Parasuraman A., ZeithamI V.A., and Berry L.1990. Delivering Quality Service: Balancing Customer Perceptions and Expectations, Free Press USA.

[21] Parasuraman., A. 1995. Measuring and Monitoring Service Quality. Chapter 6 in Understanding Services Management, Willam Glynn and James Barnes (editors), Chichester, England: John Wiley \& Sons Ltd., pp. 143-177.

[22] Parasuraman, A., ZeithamI,V.A., and Berry, L.L. 1988. SERVQUAL: A Multiple-Item Scale for Measuring Consumer Perceptions of Service Quality, Journal of Retailing, 64, pg 5-37.

[23] Parasuraman, A., Zeithaml, V.A., and Berry, L.L. 1988. SERVQUAL: A Multiple-Item Scale for Measuring Customer Perceptions of Service Quality, Journal of Retailing, pp. 12-40.

[24] Parasuraman,A., Zeithaml, V.A., and Berry,L.L. 1985. A Conceptual Model of Service Quality

[25] Randall, L., Senior, M.1992. Managing and Improving Service Quality and Delivery”, TQM Practitioner Series, Stanley Thornes (Publisher) Ltd, United Kingdom.

[26] Randheer., K. 2011. Measuring Commuters' Perception on Service Quality Using SERVQUAL in Public Transportation. International Journal of Marketing Studies Vol. 3, No. 1.

[27] Statistic Department of Malaysia 2012.

[28] Tiung., L.T. 2007. Managing High Rise Residential Building in Malaysia. Where are we? $2^{\text {nd }}$ NAPREC Conference. Malaysia.

[29] Zeithaml , V.A., Berry, L.L., and Parasuraman, A.1991. The Nature and Determinants of Customer Expectations of Service, Working Paper, Marketing Science Institute, Cambridge.

[30] Zeithaml, V.A., Berry, L.L., and Parasuraman, A.1988. Communication and Control Processes in the Delivery of Service Quality, Journal of Marketing, pp. 35-48.

[31] Zeithaml, V.A., Parasuraman, A., and Berry,L.L.1990. Delivering Quality Service - Balancing Customer Perceptions and Expectations (New York: The Free Press), 1990.

[32] Zeithaml, V.A., and Bitner, M.J. (1996), Services Marketing, McGraw-Hill, New York, NY

[33] Zeithaml, V.A., Britner. M.J., and Grembler, D.D. 2006. Service Marketing Integrating Customer Focus Across the Firm. Andy Winston Americas.

[34] Zeithaml, V.A., Parasuraman, A., and Berry, L.L. 1990. Delivering quality service: Balancing customer perceptions and expectations. New York, NY: The Free Press. 


\section{Author's biography}

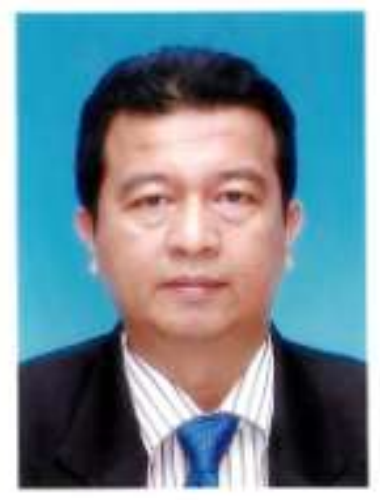

Associate Professor Sr Dr Wan Zahari Wan Yusoff

Wan Zahari Wan Yusoff is Associate Professor in the Department of Real Estate Management, Faculty of Technology Management and Business, University Tun Hussein Onn Malaysia. Currently, he is a visiting fellow at QUT, Australia. He holds a PhD in Property and Facilities Management, Master Degree in Integrated Construction Project Management, Degree in Estate Management and a Diploma in Valuation.

He has extensive experience in various sectors, including academic and non-academic and in both government and private sector. Among other positions that he had held previously are such as Deputy Director of Facilities and Property Management at UTHM (2009 -2012), Head of Research Centre, Centre of Excellence for Facilities Management, UTHM (2010 - 2012), Head of the Department of Construction Management and Real Estate, UTHM (2008-2010), Research Officer at the National Institute of Valuation (INSPEN, 2000-2003), Valuation Officer at Valuation and Property Services Department, Ministry of Finance, Malaysia (1997-2000), Assistant Valuation Officer (1993 1997), Staff on Takaful (M) Sdn. Bhd. (1988-1992) and Assistant Valuer at Property Consultant Company i.e. Azami \& Rahim \& Co. (1986-1987).

He had supervised many students at post graduate level, i.e. Masters and PhD. To date, he has successfully supervised and graduated students at the postgraduate level in research for more than 10. In appreciation to that, he was awarded by the faculty and university as the best supervisor in 2012. He also has produced a number of articles in the Real Estate and Facility Management field and to date he has published more than 20 articles in the international reviewed journals. In the community services, he was active in the areas of volunteerism and appointed as Deputy commandant which carries the title of Lieutenant Colonel for SISPA - the Civil Defense Students in UTHM. 